\title{
The Use of Apple Pomace as a Soil Amendment Enhances the Activity of Soil Microorganisms and Nitrogen Transformations and Affects Crop Growth
}

\author{
A. Nosalewicz ${ }^{1}$ (I) M. Maksim ${ }^{1} \cdot$ M. Brzezińska ${ }^{1} \cdot$ J. Siecińska ${ }^{1} \cdot$ A. Siczek ${ }^{1} \cdot$ M. Nosalewicz ${ }^{1} \cdot$ M. Turski $^{1} \cdot$ M. Frąc $^{1}$ • \\ B. Przysucha ${ }^{2} \cdot$ J. Lipiec ${ }^{1}$
}

Received: 24 November 2020 / Accepted: 7 April 2021 / Published online: 27 April 2021

(C) The Author(s) 2021

\begin{abstract}
Apple pomace (AP) is an abundant waste causing environmental problems. Therefore, the aim of the study was to evaluate the impact of AP on soil and plant growth under optimum and limited water availability. Two laboratory experiments were conducted to evaluate the impact of AP on: (i) hydrophysical properties, respiration, and N transformations in soil aggregates and (ii) the growth of wheat and faba bean in soil with addition of AP under optimum and limited water availability. The soil respiration rate increased rapidly after the introduction of AP, and the effect was dependent on the aggregate size. The reduction of nitrate and the increase in ammonium content in response to the AP addition were more pronounced in the larger aggregates. Reduced growth of wheat was noted in the dry soil supplemented with AP. Faba bean maintained its unchanged rate of growth after the application of AP, irrespective of water availability. An increase in the chlorophyll content was observed in faba bean grown in the AP-enriched soil. The apple pomace reduced the water wetting rate and increased the repellency index but did not affect the tensile strength of the soil aggregates. Disposal of AP as a soil amendment affects many indicators of soil quality. The application of AP to the soil has an impact on respiration and N transformations in the soil aggregates; moreover, it differently influences the growth of spring wheat and faba bean.
\end{abstract}

Keywords Soil quality $\cdot$ Exogenous organic matter $\cdot$ Fruit wastes $\cdot$ Nitrate $\cdot$ Ammonium $\cdot$ Drought

\section{Introduction}

The development of horticulture industries worldwide generates huge quantities of fruit wastes accounting for 25-30\% of the total amount of processed fruits (Sagar et al. 2018). Apple pomace (AP) is a leftover biomass obtained during the processing of apple fruits to produce juice, cider, or wine. Several million metric tons of apple pomace are estimated to be generated globally each year (Lyu et al. 2020), and the amount is still increasing along with the world production of apples. The ways to dispose of apple pomace include its use for feeding livestock,

A. Nosalewicz

a.nosalewicz@ipan.lublin.pl

1 Institute of Agrophysics, Polish Academy of Sciences, Doświadczalna 4, 20-290 Lublin, Poland

2 Lublin University of Technology, Nadbystrzycka 38d, 20-618 Lublin, Poland composting, fuel production, and spraying as mulch for landfilling. However, the range of its applications is relatively small at present. Hence, other applications are required to solve the issue of disposal of excess apple pomace in a sustainable and environmentally friendly manner. The disposal of AP generates high costs due to its abundance and instability after tissue disintegration and the resulting altered activity of multiple enzymes (Krasowska and Kowczyk-Sadowy 2018). Therefore, appropriate management of these wastes is a very important issue. Intensive agricultural practices lead to soil degradation, which is often characterized by a decline in the content of soil organic matter, and the use of organic wastes in agriculture is one of the modes of recycling thereof (Diacono and Montemurro 2010). This is of particular importance in sandy soils characterized by low water holding capacity and cation exchange capacity. Due to the low organic matter content and poor fertility, these soils require large amounts of irrigation and fertilizer inputs. Application of exogenous organic matter (EOM) was shown to increase the fertility of intensively used lands and organic C (OC) sequestration (Montemurro et al. 2015; Goebel et al. 2011). Many 
experimental studies indicate that EOM stimulates soil microbial activity and thus influences soil respiration and $\mathrm{N}$ transformations (Wang et al. 2019). It was also found to improve the hydraulic properties of soil by influencing soil aggregation, pore structure, wettability, and repellency (Wang et al. 2000). Such properties of soil aggregates as wettability and infiltrability help to assess the water flow rates in the conductive pores inside the aggregates (Eynard et al. 2006). Limited aggregate wettability or repellency can lead to reduced hydraulic conductivity and water infiltration into the soil (Król et al. 2015); water losses through evaporation (Shokri and Or 2011); and increased surface runoff, erosion, and risk of contamination of surface waters. Furthermore, the mechanical stability of aggregates in response to soil water repellency can be reduced due to the loss of the stabilizing effect of water menisci or increased by lower aggregate breakdown and slaking through air entrapped during wetting (Lipiec et al. 2006). Additionally, aggregates diminish microbial decomposition of organic matter and have an impact on denitrification and $\mathrm{N}$ losses (Brzezińska et al. 2018).

Spring wheat and faba bean are important crops differing strongly in their demands for soil nitrogen and water use (Adams et al. 2018), i.e., factors affected by water deficit and addition of AP. However, due to the complexity of multiple interactions, the knowledge of processes involved in the overall impact of recyclable organic wastes on soils and crops is still poor. The high water and carbohydrate contents in AP are properties that strongly differ from other better recognized sources of EOM. This is probably the first such complex evaluation of the impact of the addition of raw unprocessed apple pomace to agricultural soils.

The objective of this study was to determine the effect of AP addition to sandy soil on microbial activity, $\mathrm{N}$ transformations, and hydrophysical properties of soil aggregates. We also tested the response of spring wheat and faba bean to AP application to soil with optimum and limited water availability. We hypothesized that (1) the addition of apple pomace to soil increases microbial activity, resulting in altered $\mathrm{N}$ transformations depending on the aggregate size. (2) The reduced $\mathrm{N}$ availability in the soil resulting from the AP addition and mild water deficit does not have a negative effect on legumes due to the symbiotic association with $\mathrm{N}$-fixing bacteria.

\section{Material and Methods}

The soil used in the experiment was Podzol derived from loamy sand (Table 1). It was taken in early spring from a 0 to 30-cm-depth layer of a cultivated field (N 50.42947; E 22.60175). The soil was sieved through a 4-mm mesh to remove any debris. The soil size fractions were determined by a Mastersizer 2000 (Malvern, UK) laser diffractometer according to the procedure described by Ryżak and Bieganowski (2011). The apple pomace was the leftover of production of apple juice. It was stored in the freezer at a temperature of -24 $( \pm 2){ }^{\circ} \mathrm{C}$ until the beginning of the experimental procedures. The total phosphorus and potassium contents were determined colorimetrically and by flame photometry, respectively; the total $\mathrm{N}$ was measured according to the Kjeldahl method. The specific properties of both the soil and apple pomace are presented in Table 1.

\subsection{Experiment I: Impact of AP on Artificial Soil Aggregates}

The soil collected from the field was moistened to a field capacity, and nutrients were added in doses corresponding to $\mathrm{N}$ $\left(\mathrm{NH}_{4} \mathrm{NO}_{3}\right) 30 \mathrm{~kg} \mathrm{ha}^{-1}, \mathrm{P}\left(\mathrm{KH}_{2} \mathrm{PO}_{4}\right) 60 \mathrm{~kg} \mathrm{ha}{ }^{-1}, \mathrm{~K}\left(\mathrm{~K}_{2} \mathrm{SO}_{4}\right)$ $100 \mathrm{~kg} \mathrm{ha}^{-1}$, and $\mathrm{Mg}\left(\mathrm{MgSO}_{4} \times 7 \mathrm{H}_{2} \mathrm{O}\right) 25 \mathrm{~kg} \mathrm{ha}^{-1}$. Unmodified apple pomace was added in the dose corresponding to $20 \mathrm{t}$ of fresh mass per hectare (assuming that AP was mixed within the $0-10-\mathrm{cm}$ top soil layer, $16.7 \mathrm{~g}$ of AP was added per $1 \mathrm{~kg}$ of soil). The artificial aggregates were formed from soil with and without AP using a 6- and 10-mm-thick acrylic glass plate with drilled 6- and 10-mm-diameter holes, according to the method proposed by Józefaciuk and Czachor (2014). The specified mass of the soil was manually pressed into the holes of the plates. Then, the cylindrical aggregates with 6 and $10 \mathrm{~mm}$ diameters with $(\mathrm{AP}+)$ and without apple pomace $(\mathrm{AP}-)$ were removed from the plates. The mass of the aggregates was checked to ensure uniform density $\left(1.65 \pm 0.1 \mathrm{Mg} \mathrm{m}^{-3}\right)$.

Immediately after formation, 4 large $(10 \mathrm{~mm})$ or 16 small $(6 \mathrm{~mm})$ aggregates were carefully placed in 120-ml glass flasks. The total dry mass of the soil aggregates in the flasks ranged from approx. 4.6 to $5.4 \mathrm{~g}$ for the smaller and larger aggregates, respectively. The flasks were then airtight-closed for $2 \mathrm{~h}$ with a rubber cork prior to the first measurements of the cumulative $\mathrm{CO}_{2}$ concentration in the headspace. The concentration of $\mathrm{CO}_{2}$ was measured in $2 \mathrm{ml}$ of gas sampled using a syringe on Shimadzu GC 14A equipped with a thermal conductivity detector (TCD). After sampling of the headspace gas, the flasks were covered with aluminum foil, in which approximately 10 small holes were made with a puncture needle. The holes allowed gas exchange at a limited rate of soil drying. Unavoidable water losses were corrected by daily watering to the initial weight using a pipette. The concentration of $\mathrm{CO}_{2}$ was repeatedly measured on the 1st, 2nd, 4th, 7th, and 21st day after the formation of the aggregates. Two hours before each measurement of the $\mathrm{CO}_{2}$ concentration, the flasks were airtight-closed with a rubber plug. Cumulative $\mathrm{CO}_{2}$ emission was used to assess the respiration rate of the soil aggregates ( $\mathrm{mg} \mathrm{CO}_{2}-\mathrm{C} \mathrm{kg}^{-1}$ dry soil $\mathrm{h}^{-1}$ ). The aggregates used for the respiration and soil $\mathrm{N}$ measurements were stored in the dark at $24{ }^{\circ} \mathrm{C}$ day $(14 \mathrm{~h})$ and $18{ }^{\circ} \mathrm{C}$ night temperatures.

The impact of $\mathrm{AP}$ on soil $\mathrm{N}$ was evaluated by measurements of $\mathrm{NO}_{3}{ }^{-} \mathrm{N}$ and $\mathrm{NH}_{4}{ }^{+}-\mathrm{N}$ in the soil aggregates. Twenty-four hours and 14 days after preparation, 20-g aggregates were frozen and kept at a temperature of $-24( \pm 2) \mathrm{C}$ prior to the 
Table 1 Selected properties of apple pomace and the soil

Apple pomace $\quad$ Soil

\begin{tabular}{|c|c|c|c|c|c|c|c|c|c|c|c|c|}
\hline \multirow{2}{*}{\multicolumn{2}{|c|}{$\begin{array}{l}\mathrm{N} \\
\mathrm{mg} 100 \mathrm{~g}^{-1}\end{array}$}} & \multirow[b]{2}{*}{ K } & \multirow[b]{2}{*}{$\begin{array}{l}\mathrm{OM} \\
(\%)\end{array}$} & \multirow[b]{2}{*}{$\mathrm{C} / \mathrm{N}$} & \multirow[b]{2}{*}{$\mathrm{pH}_{\mathrm{KCl}}$} & \multirow[b]{2}{*}{$\begin{array}{l}\text { Dry matter } \\
\text { (\% wet basis) }\end{array}$} & \multicolumn{3}{|c|}{ Size fraction, $\mu \mathrm{m}(\%)$} & \multirow[b]{2}{*}{$\mathrm{pH}_{\mathrm{KCl}}$} & \multirow[b]{2}{*}{$\mathrm{OM}(\%)$} & \multirow[b]{2}{*}{$\mathrm{C} / \mathrm{N}$} \\
\hline & & & & & & & $<2$ & $2-50$ & $>50$ & & & \\
\hline $\begin{array}{l}0.496 \\
(0.010)\end{array}$ & $\begin{array}{l}0.085 \\
(0.01)\end{array}$ & $\begin{array}{l}0.81 \\
(0.03)\end{array}$ & $\begin{array}{l}98.04 \\
(0.18)\end{array}$ & $\begin{array}{l}57.77 \\
(0.19)\end{array}$ & $\begin{array}{l}4.13 \\
(0.03)\end{array}$ & $\begin{array}{l}9.9 \\
(0.1)\end{array}$ & 0.72 & 12.57 & 86.71 & $\begin{array}{l}5.35 \\
(0.02)\end{array}$ & $\begin{array}{l}0.88 \\
(0.03)\end{array}$ & $\begin{array}{l}11.99 \\
(0.41)\end{array}$ \\
\hline
\end{tabular}

The mean $(n=3)$ and standard error are shown in the brackets

measurements of the $\mathrm{NO}_{3}{ }^{-}-\mathrm{N}$ and $\mathrm{NH}_{4}{ }^{+}-\mathrm{N}$ concentrations. The concentration of $\mathrm{NO}_{3}{ }^{-}-\mathrm{N}$ and $\mathrm{NH}_{4}{ }^{+}-\mathrm{N}$ was determined in soil extracts $\left(0.01 \mathrm{MCaCl}_{2}\right)$ using a flow-type spectrophotometric analyzer FIA-Star 5010 (Foss Tecator, Sweden).

Two sizes of artificially formed soil aggregates ( 6 and $10 \mathrm{~mm})$ prepared according to the procedure described above were used for measurements of aggregate tensile strength, water and ethanol wetting rates, and the repellency index (RI). The measurements were performed after incubation for 90 days at room temperature $\left(22( \pm 2)^{\circ} \mathrm{C}\right)$. The water $\left(Q_{\mathrm{w}}\right)$ and ethanol $\left(Q_{\mathrm{e}}\right)$ wetting rates of the initially air-dried soil aggregate fractions were derived from the steady-state flow measurements conducted using an infiltration device (Lipiec et al. 2006). The rate of flow from the tube filled with either water or ethanol through the measured aggregate as a function of time was taken as a measure of the water wetting rate. The repellency index was the ratio of ethanol (not influenced by repellency) and water wetting rates calculated using a formula proposed by Leeds-Harrison et al. (1994). The $\mathrm{RI}$ (hydrophobicity) of the soil was taken as a ratio of $Q_{\mathrm{w}}$ and $Q_{\mathrm{e}}$. Due to the very rapid disintegration, the ethanol wetting rate and RI were not measured for the smaller aggregates.

Crushing strength tests were performed using ZwickLine Testing Machine Z5.0 (ZwickRoell Testing Systems GmbH, Germany). The aggregates were crushed between two steel plates at the speed of $5 \mathrm{~mm} \mathrm{~min}^{-1}$, and the first peak of force recorded was used to calculate tensile strength.

\subsection{Experiment II: Plant Response to AP}

Faba bean (Vicia faba L.) cv. Granit and spring wheat (Triticum aestivum L.) cv. Kandela were used to study the impact of the apple pomace on plant growth. The faba bean seeds were noninoculated with Rhizobium. The plants were grown in cylinders with an inner diameter of $10 \mathrm{~cm}$ and a height of $40 \mathrm{~cm}$ filled with soil characterized by a moderate bulk density of $1.5 \mathrm{Mg} \mathrm{m}^{-3}$. The apple pomace was uniformly mixed with soil from the 0 - to $10-\mathrm{cm}$ layer in a dose corresponding to $20 \mathrm{t}$ of fresh mass per ha. The soil was fertilized according to the crop demands to obtain 3 and $5 \mathrm{t}$ of faba bean and spring wheat grain yields per hectare, respectively. Therefore, the doses of N, P, K, $\mathrm{Mg}$, and $\mathrm{S}$ applied to the soil with faba bean were the same as in experiment I with the soil aggregates, and the dose of $\mathrm{N}$ in the soil with spring wheat was increased to $60 \mathrm{~kg} \mathrm{ha}^{-1}\left(\mathrm{NH}_{4} \mathrm{NO}_{3}\right)$. The initial number of three seedlings of faba bean per pot was reduced to one soon after germination. In the spring wheat variant, the initial number of approx. 10 seedlings per pot was reduced to four after germination. The different number of plants per pot yielded similar plant biomass at the end of the experiment.

The conditions during the growth of both crops were as follows: day and night temperatures $24^{\circ} \mathrm{C}(14 \mathrm{~h})$ and $18{ }^{\circ} \mathrm{C}$, photosynthetic active radiation $150 \mu \mathrm{mol}$ photons $\mathrm{m}^{-2} \mathrm{~s}^{-1}$, and relative air humidity $60 \%$. Both plant species were grown for 63 days and subjected to the following treatments: (1) C AP-: optimum soil water availability without addition of apple pomace; (2) C AP+: optimum soil water availability with addition of apple pomace; (3) D AP-: mild water deficit without addition of apple pomace; (4) D AP+: mild water deficit with addition of apple pomace. The soil water potential was maintained at the optimum level corresponding to field capacity at the soil water potential of - $33 \mathrm{kPa}$ throughout the experimental period. Soil in the treatments with water deficit had an optimum water potential during the first 14 days after sowing; then, water deficit conditions were induced to maintain the soil water potential in the range from 80 to $-60 \mathrm{kPa}$ until cutting the plants at the end of the experiment. Specific soil water availability was maintained by watering the experimental cylinders to the specified weight every $24 \mathrm{~h}$.

Leaf chlorophyll content was measured at day 63 using a Chlorophyll Content Meter CCM-300 (Opti-Sciences, Inc., USA) in the middle section of fully expanded leaves.

Leaf gas exchange was measured every fifth day starting from the beginning of limited watering. The measurement was conducted using a GFS3000 gas-exchange system equipped with a standard measuring head 3100-S (Walz GmbH, Germany). The conditions in the head chamber with the leaf were the same as in the growth chamber, and the $\mathrm{CO}_{2}$ concentration during the measurements was 400 ppm.

Leaf relative water content (RWC) was determined at day 63 in the first fully developed leaves. Excised leaves were immediately weighed to obtain fresh weight $(\mathrm{FW})$, rehydrated in distilled water for $24 \mathrm{~h}$, and weighed again to determine turgid weight (TW). Dry weight (DW) was determined after drying at $105^{\circ} \mathrm{C}$ 
to constant mass. Relative water content was calculated using the equation: $\mathrm{RWC}=(\mathrm{FW}-\mathrm{DW}) /(\mathrm{TW}-\mathrm{DW}) \cdot 100$.

The presented data are the mean and standard error values (unless indicated otherwise) of the measurements of the plant or soil material (exact $n$ is specified under the figures). Statistical analysis of the results was performed using confidence tests with the ANOVA analysis of variance (STATISTICA 13, StatSoft Inc.). Normality was evaluated using residual analysis (for $n \leq 4)$; in other cases $(n>4)$, the Shapiro-Wilk test was used. The means were compared with the use of the HSD Tukey test at $p<0.05$.

\section{Results}

\section{1 $\mathrm{CO}_{2}$ Respiration and $\mathrm{N}$-Transformations in Soil Aggregates}

The respiration rate in soil aggregates with both diameters formed without addition of AP was relatively constant throughout the 21-day period of the measurements (Fig. 1), with a mean of 3.8 and $3.3 \mathrm{mg} \mathrm{CO}_{2}-\mathrm{C} \mathrm{kg}^{-1} \mathrm{~h}^{-1}$ for the 6- and $10-\mathrm{mm}$ aggregates, respectively. The difference in the respiration rate between the small and large non-amended (AP-) aggregates was significant only at the beginning.

The level of $\mathrm{CO}_{2}$ evolved from the aggregates with AP $(\mathrm{AP}+)$ was significantly higher $(p<0.05)$ throughout the $21-$ day period with than without AP. The highest difference between AP+ and AP-, i.e., over 5.5 times and 4.0 times for the 6- and 10-mm aggregates, respectively, was noted after $24 \mathrm{~h}$. Next, the differences between aggregates with and without AP slowly decreased but were still significant at the end of the incubation in both the smaller and larger aggregates.

Similar to the respiration rate, the decrease in the $\mathrm{NO}_{3}{ }^{-} \mathrm{N}$ content occurred as early as $24 \mathrm{~h}$ after the addition of apple pomace (Fig. 2). The AP amendment significantly affected the nitrate- $\mathrm{N}$ and ammonium- $\mathrm{N}$ contents in the soil aggregates. Already, after $24 \mathrm{~h}$, the concentration of $\mathrm{NO}_{3}{ }^{-} \mathrm{N}$ was lower by $22 \%\left(8.1 \mathrm{mg} \mathrm{kg}^{-1}\right)$ and $27 \%\left(10.5 \mathrm{~kg}^{-1}\right)$ in the small and large $\mathrm{AP}+$ aggregates, respectively, compared to the $\mathrm{AP}-\mathrm{ag}-$ gregates. The differentiation in the $\mathrm{N}$-ammonium concentration was even higher, as $\mathrm{NH}_{4}{ }^{+}-\mathrm{N}$ was by $87 \%\left(14.6 \mathrm{~kg}^{-1}\right)$ and $91 \%\left(16.8 \mathrm{~kg}^{-1}\right)$ lower in the small and large AP+ aggregates, respectively, compared to the AP- aggregates.

After 14 days of incubation, the nitrate content in the APaggregates was slightly higher than initially, but strongly decreased in the AP+ aggregates. Therefore, the AP amendment resulted in a $93 \%$ and $78 \%$ decline in $\mathrm{NO}_{3}{ }^{-} \mathrm{N}$ in the small and large $\mathrm{AP}+$, respectively, compared to the $\mathrm{AP}-$ aggregates. The ammonium concentration strongly decreased in the AP- aggregates during the 14-day incubation period and apparently increased in the $\mathrm{AP}+$ aggregates. Consequently, the level of
$\mathrm{NH}_{4}{ }^{+} \mathrm{N}$ differed significantly (3-fold), but only between the large $\mathrm{AP}-$ and $\mathrm{AP}+$ aggregates.

\subsection{Hydrophysical Properties of the Aggregates}

Although the tensile strength of the aggregates was not affected by the apple pomace (Fig. 7, Appendix), the addition of AP significantly $(p<0.05)$ decreased the water wetting rate, as shown in Fig. 3. This reduction was more pronounced in the 10-mm aggregates (on average by $18.1 \%$ ) than in the 6-mm ones (on average by $10.1 \%$ ). In both treatments, the water wetting rate was higher in the larger aggregates. The ethanol wetting rate (measured only for the 10-mm aggregates) was not significantly different between the variants with and without the AP treatment. The repellency index (RI) for the 10-mm aggregates was significantly higher in the AP+ than AP- treatment.

\subsection{Growth of Spring Wheat and Faba Bean}

The mild water deficit was induced to test the growth of plants in conditions that would additionally limit $\mathrm{N}$ availability. It was assumed that the reduced soil water availability decreased root water and dissolved nitrogen uptake. The measurements of leaf gas exchange (data not presented) showed that the average decline in transpiration from the first fully developed leaves of faba bean and spring wheat was approx. $38 \%$ and $25 \%$, respectively, in the water deficit conditions, compared to the optimum conditions. The corresponding decrease in photosynthesis was much less pronounced and reached $1.9 \%$ and $12.9 \%$ for each of the crops.

The mild water deficit induced in the early growth stage had a significant negative impact on both crops. The results indicate that, for both of the crops, there was no significant impact of the AP addition to the soil on the aboveground plant biomass at the optimal soil water availability (Fig. 4). However, in the dry soil, there was a significant decline in the shoot biomass in the spring wheat growing in the soil with AP, compared to the APtreatment. The growth of faba bean was not negatively influenced by the addition of AP to the dry soil; similarly, no significant response to AP was noted for the biomass of root nodules (Fig. 8, Appendix).

The limitation in $\mathrm{N}$ availability to the plants in the presence of apple pomace was likely induced by the decrease in the $\mathrm{NO}_{3}{ }^{-}-\mathrm{N}$ content. This effect occurred in soil aggregates where a several-fold decrease in the $\mathrm{NO}_{3}{ }^{-}-\mathrm{N}$ concentration was noted after the addition of AP (Fig. 2).

The increase in the chlorophyll concentration in the leaves is an indirect indicator of the enhanced $\mathrm{N}$ uptake by faba bean from the AP+ soil (Fig. 5). Importantly, this effect was accompanied by an increase in shoot biomass (Fig. 4) at optimum and reduced water availability. In turn, no impact of the apple pomace on leaf chlorophyll was noted in wheat growing in the wet soil, but a 
Fig. 1 Respiration rate in 6-mmand 10 -mm-diameter cylindrical soil aggregates at $4 \mathrm{~h}$ ( 0 day) and on successive days after the formation of the aggregates from soil without apple pomace (AP-) and soil with the addition of apple pomace $(\mathrm{AP}+)$. The mean $(n=4)$ and standard error are shown; the different letters indicate statistical differences on the particular days at $p<0.05$

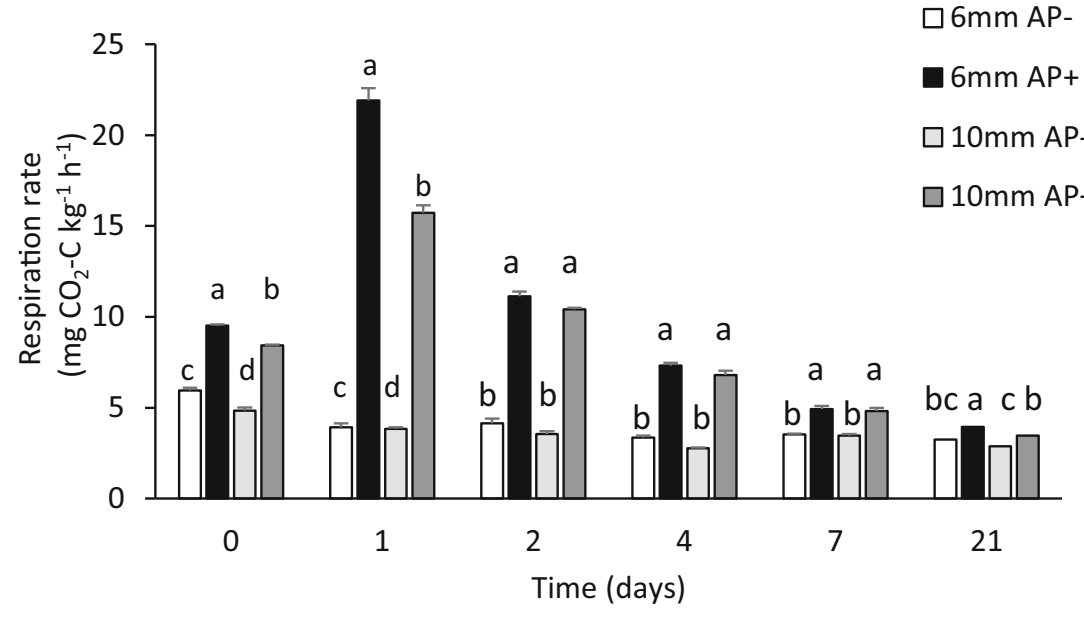

The comparison of the relative water content (RWC) in the leaves of the studied crops (Fig. 6) indicates that the intensity significant drop occurred in the leaves of the plants grown in the dry soil with the AP addition.

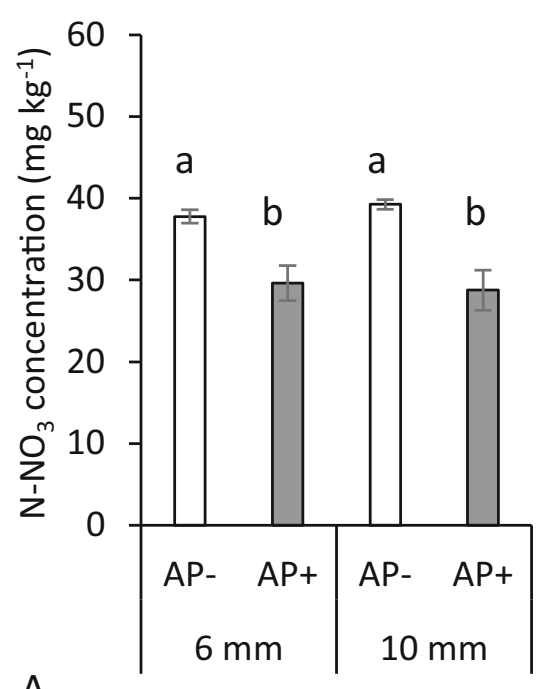

A

Fig. 2 Concentration of nitrate-N (A, C) and ammonium-N (B, D) in 6-mm- and 10-mm-diameter artificial soil aggregates at $24 \mathrm{~h}$ (A, B) and on day 14 (C, D) after the formation of the aggregates without (AP-) and with apple pomace $(\mathrm{AP}+)$. The mean $(n=3)$ and standard error are shown; the different letters indicate statistical differences at $p<0.05$

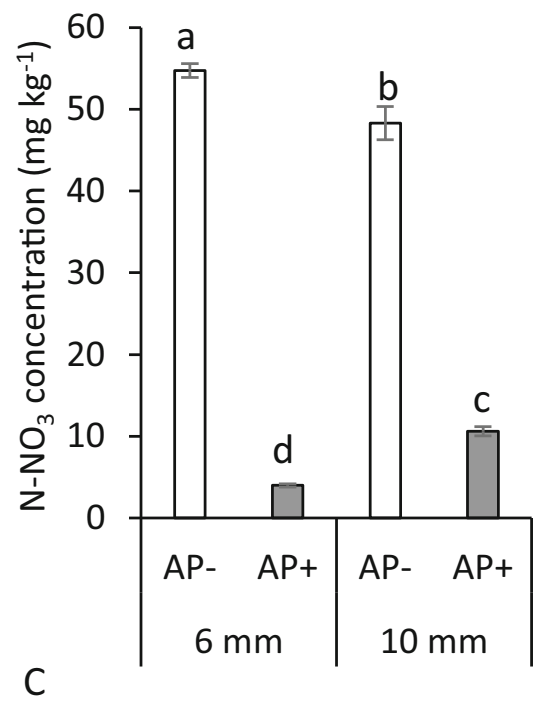

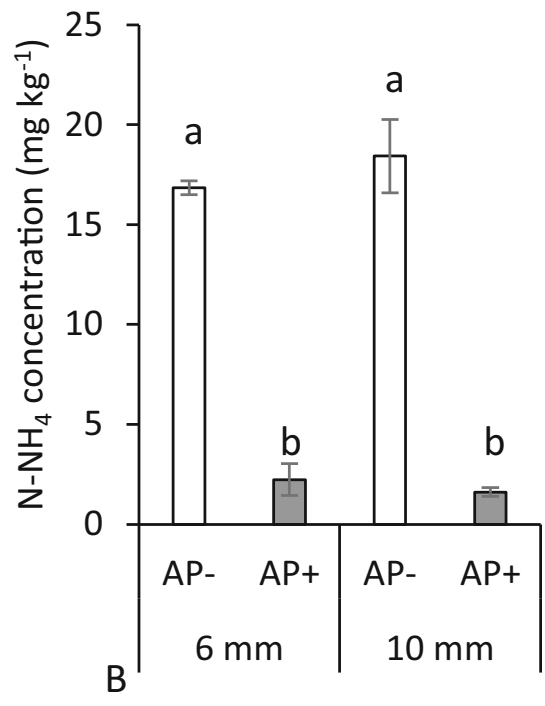

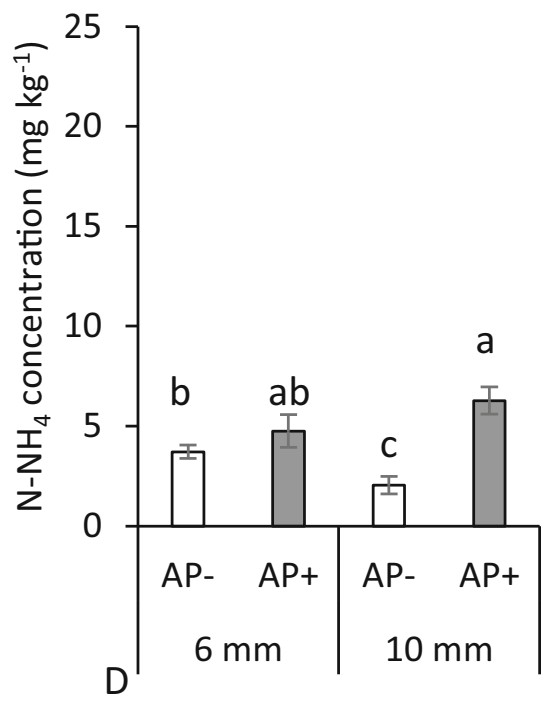




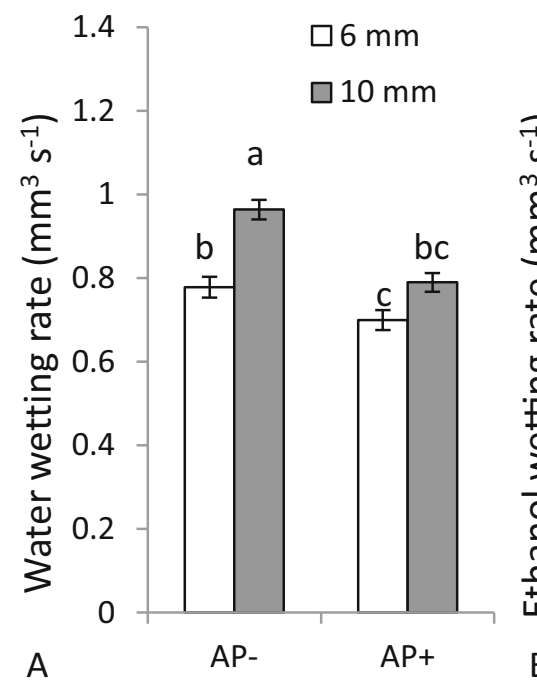

Fig. 3 Hydraulic properties of 6-mm and 10-mm soil aggregates with $(\mathrm{AP}+)$ and without apple pomace ( $\mathrm{AP}-)$ after 90 days of incubation. The ethanol wetting rate and repellency index (RI) were not measured

of water deficit was generally low, as the faba bean leaves did not exhibit any significant dehydration, compared to the control plants. The wheat leaves had significantly lower RWC when grown in the soil with restricted watering and addition of the apple pomace, while no differences were noted in the $\mathrm{AP}-$ treatments.

\section{Discussion}

The addition of apple pomace stimulated microbial respiration of the aggregates due to the presence of easily available carbohydrates (Fig. 1). The decline in the nitrate content in the AP+ aggregates already after $24 \mathrm{~h}$ and, to a much greater extent, after

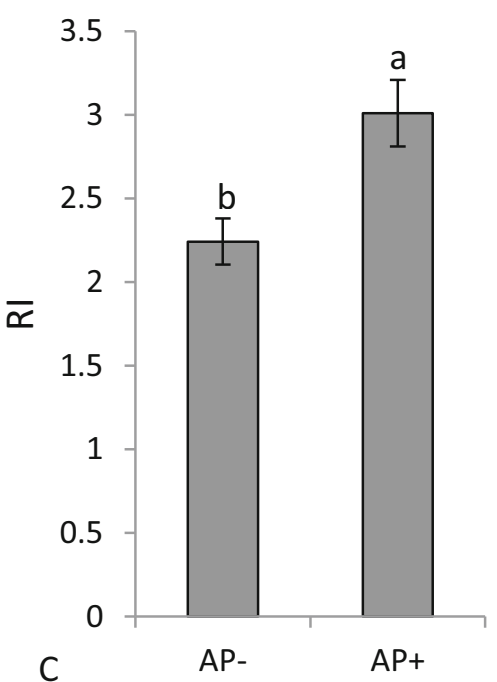

for the 6-mm aggregates due to their very rapid disintegration. The mean $(n=15-18)$ and standard error are shown; the different letters indicate statistical differences at $p<0.05$ between objects with and without AP

14 days of incubation was likely due to assimilation by the growing microbes. Simultaneously, the intensive respiration at the beginning of the incubation (see Fig. 1) suggests rapid oxygen uptake. In the anaerobic parts of the aggregates, following $\mathrm{O}_{2}$ depletion, facultative anaerobes shift their metabolism and use $\mathrm{NO}_{3}{ }^{-}$as electron acceptors during denitrification (Włodarczyk et al. 2014). The significant difference in the $\mathrm{NH}_{4}{ }^{+}-\mathrm{N}$ contents between the $\mathrm{AP}+$ and $\mathrm{AP}-$ aggregates after $24 \mathrm{~h}$ of incubation may have been due to the intensive $\mathrm{N}$ assimilation associated with the rapid growth of microbial communities stimulated by apple pomace. After 14 days, AP added to the smaller aggregates ( $6 \mathrm{~mm}$ ) had no impact on the $\mathrm{NH}_{4}-\mathrm{N}$ content, whereas the significant increase in the content of $\mathrm{NH}_{4}{ }^{+}-\mathrm{N}$ in the $10-\mathrm{mm} \mathrm{AP+}$ aggregates may have resulted from dissimilatory nitrate reduction
Fig. 4 Shoot dry mass (SDM) of faba bean (A) and spring wheat (B) grown in the dry soil (D) and soil with optimum water availability $(\mathrm{C})$ without (AP-) and with the addition of apple pomace $(\mathrm{AP}+)$. The mean for the plant species $(n=4$ for faba bean and $n=16$ for spring wheat) and standard error are shown; the different letters indicate statistical differences at $p<0.05$
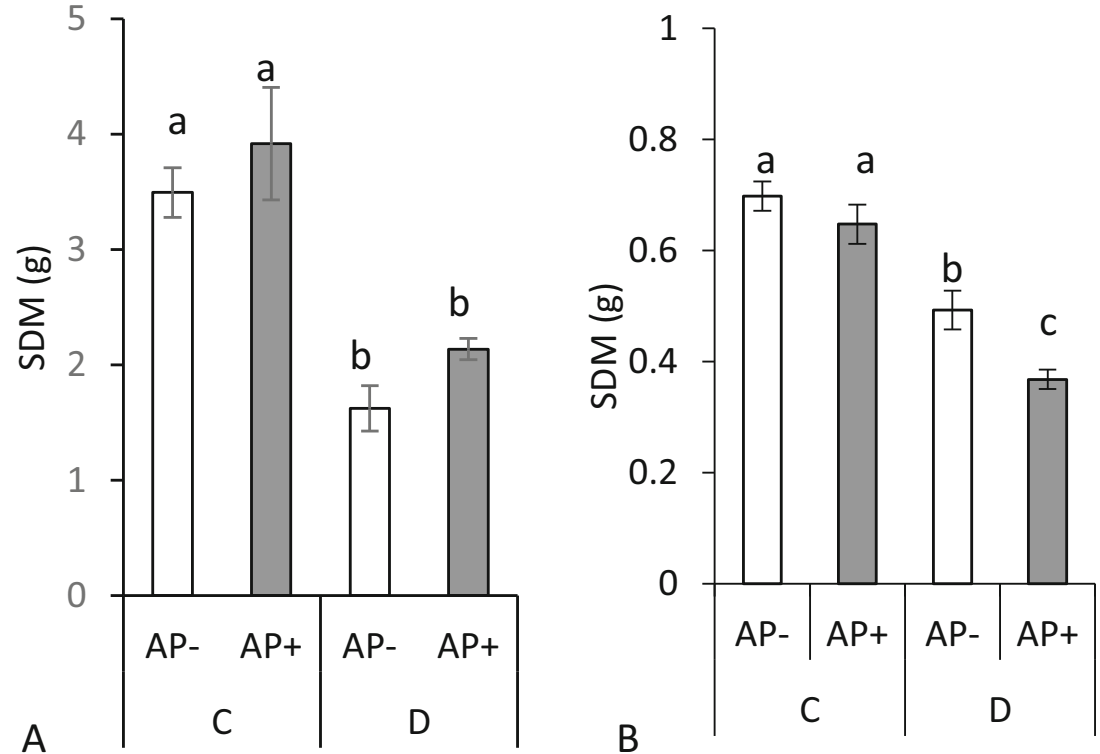
Fig. 5 Concentration of chlorophyll in the first fully developed leaves of faba bean (A) and wheat (B) grown in soil with optimum (C) and limited (D) water availability without (AP-) and with the addition of apple pomace $(\mathrm{AP}+)$. The mean $(n=$ 12) and standard error are shown; the different letters indicate statistical differences at $p<0.05$
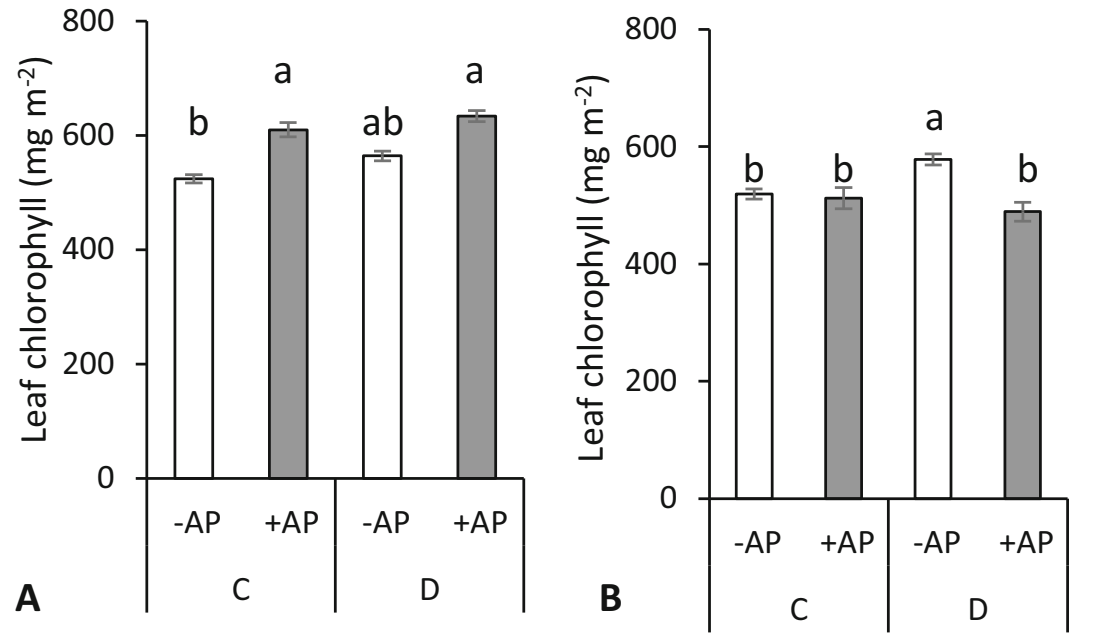

to ammonium (DNRA), which occurs in anaerobic conditions as an alternative mechanism to denitrification (Silver et al. 2001). Dissimilatory nitrate reduction to ammonium strongly increases in anaerobic soil amended with easily available C (Levy-Booth et al. 2014). In fact, the importance of DNRA in soil is its capacity to increase $\mathrm{N}$ retention, because nitrate is transformed to ammonium, which is less prone to losses via leaching or as gaseous compounds (Rütting et al., 2011). The core of the larger aggregate is more susceptible to anaerobic conditions due to the lower surface-to-volume ratio. The larger 10-mm aggregates were characterized by a nearly 2 -fold lower ratio of the surface area to their volume than the 6-mm aggregates. Natural mineralization may also have been involved in the observed increase in the $\mathrm{NH}_{4}{ }^{+}-\mathrm{N}$ concentration (Carswell et al. 2018). Although the soil used in the experiment was characterized by the $\mathrm{pH}$ below optimum for denitrification (Table 1) it appears that high availability of carbon from AP and nitrate from fertilizer $\left(\mathrm{NH}_{4} \mathrm{NO}_{3}\right)$ at anaerobic sites sufficiently stimulated the process. Čuhel et al. (2010) explained high denitrification rates in acid soil used in their experiment by nonlimiting denitrifying conditions, i.e., soil incubation at $25^{\circ} \mathrm{C}$ with limited oxygen, addition of $\mathrm{NO}_{3}{ }^{-}$and glucose.

Decomposition processes in soil are controlled by the $\mathrm{C} / \mathrm{N}$ ratio, and addition of fresh organic matter accelerates soil biogeochemical processes. When the $\mathrm{C} / \mathrm{N}$ ratio in the added organic substrate ranges from 1 to 15 , rapid mineralization and release of plant available $\mathrm{N}$ occurs (the lower the $\mathrm{C} / \mathrm{N}$ ratio, the more rapid the release of available $\mathrm{N}$ into the soil), while the $\mathrm{C} / \mathrm{N}$ ratio $>35$ results in microbial immobilization (Brust 2019). Although apple pomace added in our study showed the $\mathrm{C} / N=57.8$, soil respiration was significantly higher in enriched aggregates over 21 days of the incubation. Soil microorganisms compete with plants for nitrogen and other nutrients in soil and decompose soil organic matter, plant litter, and organic residues with very wide $\mathrm{C} / \mathrm{N}$ ratios (Vitousek et al. 2002). Therefore, the properties of added organic materials influence soil nutrient status. Huang et al. (2004) tested the effect of different plant residues (with a $\mathrm{C} / \mathrm{N}$ ratio from 8 to 118) on $\mathrm{CO}_{2}$ and $\mathrm{N}_{2} \mathrm{O}$ emissions from soil $(\mathrm{C} / \mathrm{N}$ of 12.8) and reported that cumulative gas emissions were
Fig. 6 Relative water content (RWC) in the leaves of faba bean (A) and wheat (B) grown in soil with optimum (C) and limited (D) water availability without (AP-) and with the addition of apple pomace (AP+). The mean $(n=4)$ and standard error are shown; the different letters indicate statistical differences at $p<0.05$
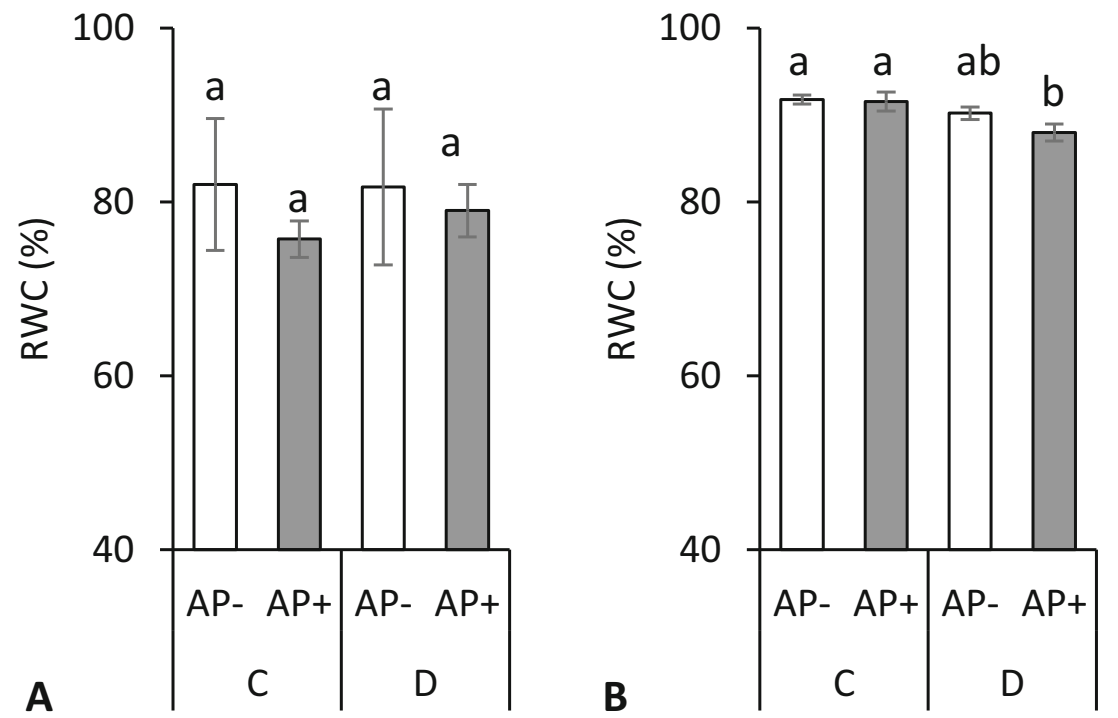
negatively correlated with the $\mathrm{C}$ to $\mathrm{N}$ ratio in the added residues. Apparently, the incorporation of immature organic matter such as apple pomace (with $\mathrm{C} / \mathrm{N}=57.8$ ) induced both microbial $\mathrm{C}$ and $\mathrm{N}$ transformations. Significant stimulation of soil respiration and the decrease in the nitrate content in the $\mathrm{AP}+$ treatments were observed already at the beginning of the incubations (Figs. 2 and 3). Besides, AP+ had an adverse effect on wheat growth (Fig. $4 \mathrm{~b}$ ), which may suggest $\mathrm{N}$-deficiency.

Since apple pomace was found to stimulate soil microbial activity and accelerate $\mathrm{N}$ transformation, its addition to soil may reduce $\mathrm{NO}_{3}{ }^{-} \mathrm{N}$ and thus decrease the potential risk of $\mathrm{N}$ leaching. This can be clearly seen from the strong drop in $\mathrm{NO}_{3}{ }^{-}$-N on day 14 after application of AP (Fig. 2). Larney and Angers (2012) showed that EOM with low N content, as in the apple pomace, reduced $\mathrm{N}$ availability to plants mostly via stimulation of denitrification with formation of $\mathrm{N}_{2}$. On the other hand, apple pomace applied during aerobic composting of pig manure conserved $\mathrm{NH}_{4}{ }^{+}-\mathrm{N}$ and $\mathrm{NO}_{3}{ }^{-} \mathrm{N}$ contents by inhibition of $\mathrm{NH}_{3}$ and $\mathrm{N}_{2} \mathrm{O}$ emission (Mao et al. 2017).

Soil aggregates are essential components affecting the soil structure. They determine the soil-water relationships, which are especially important during seedling establishment and early growth. Soil microorganisms can improve soil aggregate stability through production of extracellular polysaccharides. The increase in the microbial activity after the addition of AP was evidenced by the increase in the soil respiration rates (Fig. 1). Moreover, a positive correlation between aggregate stability and the dose of organic amendments was also observed in experiments on sandy loam textured soil with addition of various organic wastes, including AP (Yilmaz 2014).

The wetting rate is one of the soil aggregate characteristics that determines the stability of the soil structure (An and Liu 2017), especially during rainfalls when aggregate breakdown is caused by rapid release of entrapped air. We observed a decrease in the wetting rate of both aggregates (Fig. 3), indicating that addition of AP can decrease soil susceptibility to the erosion process. As demonstrated by Urbanek et al. (2007), aggregates from both treatments can be classified as subcritically waterrepellent $(1.95<\mathrm{RI}<50)$. The approximately $34 \%$ increase in RI after the addition of apple pomace (Fig. 3) may have additional consequences for prediction of water flow in soil. Indeed, Vogelmann et al. (2017) observed that an altered RI of soil aggregates modifies the water infiltration behavior especially during droughts. The experiment conducted by Cesarano et al. (2016) showed that the increase in water repellency in sandy loam soil occurs independently of the plant litter type until it is in an undecomposed state. The increase in the repellency of the soil aggregates observed in our experiment after the apple pomace addition may depend on the decomposition of soil organic matter. Indeed, Goebel et al. (2011) suggested a close relationship between the stability of soil organic matter and water repellency, as the resistance of organic matter to microbial decomposition is increased in water-repellent soils. The non-statistically different (at $p<0.05$ ) wetting rate of ethanol (which easily infiltrates hydrophobic soil) between the $\mathrm{AP}+$ and $\mathrm{AP}-$ treatments (Fig. 3b) implies that the significantly lower water wetting rate of the AP+ vs. AP- aggregates (Fig. 3a) and the higher repellency index (RI) can be related to the increasing content of hydrophobic compounds from AP and enhanced microbial activity (Peng et al. 2003). Furthermore, the addition of organic C from AP characterized by low $\mathrm{pH}$, at which the solubility of humid acids decreases and the surface tension of water increases (Hurraß and Schaumann 2006), can further elucidate the higher repellency index in the AP+ aggregates (Fig. 3). The increase in repellency can be enhanced by the low surface area of the coarse-textured soil used in this study, which requires a lower quantity of hydrophobic organic matter to coat soil particles, compared to finetextured soil (Hajnos et al. 2013).

The addition of the AP to the soil had different effects on both studied crops. The faba bean biomass was not affected by AP, but the leaf chlorophyll content was higher in plants growing in soil with optimum soil water availability and AP addition. In turn, the spring wheat was affected by AP only in the dry soil, at which a negative impact of AP on biomass and leaf chlorophyll was noted. Crops are generally differentiated in their response to water deficit, and this relation depends on plant-soil microorganism interactions (Naylor and Coleman-Derr 2018).

Hirich et al. (2013) showed that organic amendment improved biomass production of quinoa under water deficit. In our study, faba bean responded better than the spring wheat to the mild water deficit in the soil amended with AP (Fig. 4). As shown by Zheng and Shetty (2000), the beneficial impact of AP on pea growth depended on the presence of Trichoderma species producing specific plant growth stimulating substances from AP. Although we did not examine the impact of the AP application on the biodiversity of soil microorganisms, the Trichoderma genus is common in soil and rhizosphere. Beneficial impact of soil the microorganism-plant interactions may have been enhanced after the AP application, resulting in increased microbial activity (Fig. 1) maintaining the growth of faba bean (Fig. 4) in the soil of limited $\mathrm{N}$ and water. In contrast to olive pomace amendment, which had no effect on available $\mathrm{N}$ in soil (Innangi et al. 2017), the AP application decreased the $\mathrm{N}$ availability to plants, especially in the drought conditions. As reported by Eschen et al. (2006), addition of easily available $C$ to the soil decreases the inorganic $\mathrm{N}$ concentration due to immobilization of $\mathrm{N}$ by resident soil bacteria and fungi. In the conditions of their experiment, the growth of legumes appeared to be much less dependent on soil $\mathrm{N}$ than in the case of the grasses due to the symbiotic association with $\mathrm{N}$-fixing bacteria in the root nodules of legumes. This may explain the higher chlorophyll concentration in the faba bean leaves (Fig. 5) and at the same time the lack of an adverse effect of the AP addition on faba bean growth. Additionally, as indicated earlier, water stress and nitrogen deficiency induced structural changes in nodule anatomy connected with changes in nitrogenase activity (Mrema et al., 1997). 


\section{Conclusions}

The impact of apple pomace on the soil respiration and the concentration of nitrate and ammonium nitrogen in soil aggregates depends on their size, as larger aggregates are more susceptible to anaerobic conditions. The tensile strength of the aggregates in the present study was not affected by the apple pomace, whereas the water repellency index was higher in the apple pomace-amended than the non-amended soil. The decreased $\mathrm{N}$ availability related to the water deficit and addition of the AP to the soil exerted different effects on the growth of faba bean and spring wheat. A negative impact on the growth performance of wheat was noted in the apple pomace-amended soil in the water deficit conditions, but there was no such a negative response in the case of the faba bean due to the symbiotic association with $\mathrm{N}$-fixing bacteria. Apple pomace had also a positive effect on the content of leaf chlorophyll in the faba bean. The results show that AP can be disposed of without any special pre-processing as a soil amendment under faba bean, irrespective of soil water availability. Further studies are needed to investigate inoculation of AP with plant growth-promoting microorganisms, which potentially may enhance crop yields.

\section{Appendix}

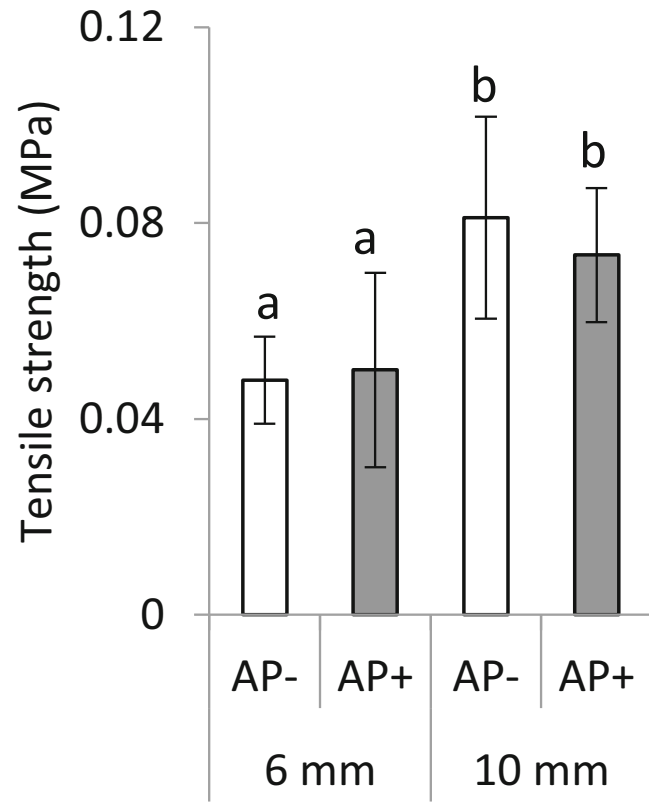

Fig. 7 Tensile strength of air-dried artificial soil aggregates without (AP - ) and with apple pomace (AP+) after 90 days of incubation. The mean $(n=40)$ and standard deviation are shown; the different letters indicate statistical differences at $p<0.05$ between aggregates with the same diameter

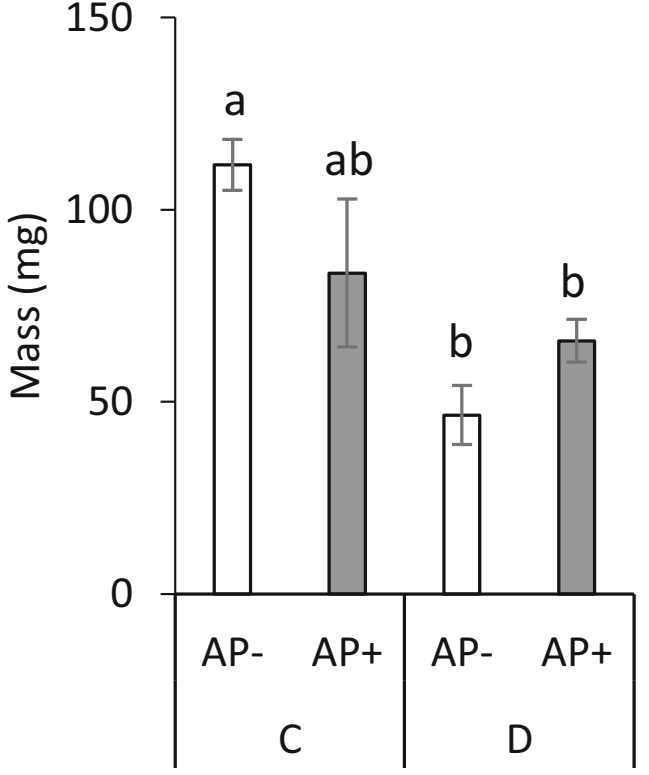

Fig. 8 Dry mass of faba bean root nodules per plant growing in soil without $(\mathrm{AP}-)$ and with apple pomace $(\mathrm{AP}+)$ in soil with optimum $(\mathrm{C})$ and limited (D) water availability. The mean $(n=4)$ and standard error are shown; the different letters indicate statistical differences at $p<0.05$

Availability of Data and Material (Data Transparency) Data will be available on request.

Code Availability (Software Application or Custom Code) Not applicable.

Funding The research was conducted as part of the statutory activity of the Institute of Agrophysics Polish Academy of Sciences.

\section{Declarations}

Ethics Approval (Include Appropriate Approvals or Waivers) Not applicable.

Consent to Participate (Include Appropriate Statements) Not applicable.

Consent for Publication (Include Appropriate Statements) Not applicable.

Conflict of Interest The authors declare no competing interests.

Open Access This article is licensed under a Creative Commons Attribution 4.0 International License, which permits use, sharing, adaptation, distribution and reproduction in any medium or format, as long as you give appropriate credit to the original author(s) and the source, provide a link to the Creative Commons licence, and indicate if changes were made. The images or other third party material in this article are included in the article's Creative Commons licence, unless indicated otherwise in a credit line to the material. If material is not included in the article's Creative Commons licence and your intended use is not permitted by statutory regulation or exceeds the permitted use, you will need to obtain permission directly from the copyright holder. To view a copy of this licence, visit http://creativecommons.org/licenses/by/4.0/. 


\section{References}

Adams MA, Buckley TN, Salter WT, Buchmann N, Blessing CH, Turnbull TL (2018) Contrasting responses of crop legumes and cereals to nitrogen availability. New Phytol 217:1475-1483. https://doi.org/10.1111/nph.14918

An J, Liu QJ (2017) Soil aggregate breakdown in response to wetting rate during the inter-rill and rill stages of erosion in a contour ridge system. CATENA 157:241-249. ISSN 0341-8162. https://doi.org/ 10.1016/j.catena.2017.05.027

Brust GE (2019) Management strategies for organic vegetable fertility in safety and practice for organic food. In: Biswas D, Micallef SA (eds) Safety and practice for organic food. Academic Press, pp 193-212. https://doi.org/10.1016/B978-0-12-812060-6.00009-X

Brzezińska M, Lipiec J, Frąc M, Oszust K, Szarlip P, Turski M (2018) Quantitative interactions between total and specific enzyme activities and $\mathrm{C}$ and $\mathrm{N}$ contents in earthworm-affected pear orchard soil. Land Degrad Dev 29:3379-3389. https://doi.org/10.1002/ldr.3100

Carswell AM, Hill PW, Jones DL (2018) Impact of microbial activity on the leaching of soluble $\mathrm{N}$ forms in soil. Biol Fertil Soils 54:21-25. https://doi.org/10.1007/s00374-017-1250-9

Cesarano G, Incerti G, Bonanomi G (2016) The influence of plant litter on soil water repellency: insight from 13C NMR spectroscopy. PLoS One 11:e0152565. https://doi.org/10.1371/journal.pone. 0152565

Čuhel J, Šimek M, Laughlin RJ, Bru D, Chèneby D, Watson CJ, Philippot L (2010) Insights into the effect of soil $\mathrm{pH}$ on $\mathrm{N}_{2} \mathrm{O}$ and $\mathrm{N}_{2}$ emissions and denitrifier community size and activity. Appl Environ Microbiol 76:1870-1878. https://doi.org/10.1128/AEM. 02484-09

Diacono M, Montemurro F (2010) Long-term effects of organic amendments on soil fertility. A review. Agron Sustain Dev 30:401-422. https://doi.org/10.1007/978-94-007-0394-0_34

Eschen R, Müller-Schärer H, Schaffner U (2006) Soil carbon addition affects plant growth in a species-specific way. J Appl Ecol 43:3542. https://doi.org/10.1111/j.1365-2664.2005.01110.x

Eynard A, Schumacher TE, Lindstrom MJ, Malo DD, Kohl RA (2006) Effects of aggregate structure and organic C on wettability of Ustolls. Soil Tillage 88:205-216. https://doi.org/10.1016/j.still. 2005.06.002

Goebel M, Bachmann J, Reichstein M, Janssens IA, Guggenberger G (2011) Soil water repellency and its implications for organic matter decomposition-is there a link to extreme climatic events? Glob Chang Biol 17:2640-2656. https://doi.org/10.1111/j.1365-2486. 2011.02414.x

Hajnos M, Całka A, Józefaciuk G (2013) Wettability of mineral soils. Geoderma 206:63-69. https://doi.org/10.1016/j.geoderma.2013.04. 019

Hirich A, Choukr-Allah R, Jacobsen SE (2013) The combined effect of deficit irrigation by treated wastewater and organic amendment on quinoa (Chenopodium quinoa Willd.) productivity. Desalin Water Treat 52:10-12. https://doi.org/10.1080/19443994.2013.777944

Huang Y, Zou J, Zheng X, Wang Y, Xu X (2004) Nitrous oxide emissions as influenced by amendment of plant residues with different $\mathrm{C}$ : N ratios. Soil Biol Biochem 36:973-981. https://doi.org/10.1016/j. soilbio.2004.02.009

Hurraß J, Schaumann GE (2006) Properties of soil organic matter and aqueous extracts of actually water repellent and wettable soil samples. Geoderma 132:222-239. https://doi.org/10.1016/j.geoderma. 2005.05 .012

Innangi M, Niro E, D’Ascoli R, Danise T, Proietti P, Nasini L, Regni L, Castaldi S, Fioretto A (2017) Effects of olive pomace amendment on soil enzyme activities. Appl Soil Ecol 119:242-249. https://doi.org/ 10.1016/j.apsoil.2017.06.015
Józefaciuk G, Czachor H (2014) Impact of organic matter, iron oxides, alumina, silica and drying on mechanical and water stability of artificial soil aggregates. Assessment of new method to study water stability. Geoderma 221-222:1-10. https://doi.org/10.1016/j. geoderma.2014.01.020

Krasowska M, Kowczyk-Sadowy M (2018) Evaluation of the possibility of using apple pomace for fertilizing purposes. J Res Appl Agric Eng 63:89-93

Król A, Lipiec J, Frąc M (2015) The effect of dairy sewage sludge amendment on repellency and hydraulic conductivity of soil aggregates from two depths of Eutric Cambisol. J Plant Nutr Soil Sci 178: 270-277. https://doi.org/10.1002/jpln.201400231

Larney FJ, Angers DA (2012) The role of organic amendments in soil reclamation: a review. Can J Soil Sci 92:19-38. https://doi.org/10. 4141/cjss2010-064

Leeds-Harrison PB, Youngs EG, Uddin B (1994) A device for determining the sorptivity of soil aggregates. Eur J Soil Sci 45:269-272. https://doi.org/10.1111/j.1365-2389.1994.tb00509.x

Levy-Booth DJ, Prescott CE, Grayston SJ (2014) Microbial functional genes involved in nitrogen fixation, nitrification and denitrification in forest ecosystems. Soil Biol Biochem 75:11-25. https://doi.org/ 10.1016/j.soilbio.2014.03.021

Lipiec J, Kuś J, Nosalewicz A, Turski M (2006) Tillage system effects on stability and sorptivity of soil aggregates. Int Agrophys 20:189-193

Lyu F, Luiz SF, Azeredo DRP, Cruz AG, Ajlouni S, Ranadheera CS (2020) Apple pomace as a functional and healthy ingredient in food products: a review. Processes 8:319. https://doi.org/10.3390/ pr8030319

Mao H, Zhang T, Li R, Zhai B, Wang Z, Wang Q, Zhang Z (2017) Apple pomace improves the quality of pig manure aerobic compost by reducing emissions of $\mathrm{NH}_{3}$ and $\mathrm{N}_{2} \mathrm{O}$. Sci Rep 7:870. https://doi. org/10.1038/s41598-017-00987-y

Montemurro F, Ciaccia C, Leogrande R, Ceglie F, Diacono M (2015) Suitability of different organic amendments from agro-industrial wastes in organic lettuce crops. Nutr Cycl Agroecosyst 102:243252. https://doi.org/10.1007/s10705-015-9694-5

Mrema AF, Granhall U, Sennerby-Forsse L (1997) Plant growth, leaf water potential, nitrogenase activity and nodule anatomy in Leucaena leucocephala as affected by water stress and nitrogen availability. Trees 12:42-48. https://doi.org/10.1007/PL00009695

Naylor D, Coleman-Derr D (2018) Drought stress and root-associated bacterial communities. Front Plant Sci 8:2223. https://doi.org/10. 3389/fpls.2017.02223

Peng X, Zhang B, Zhao Q, Horn R, Hallett PD (2003) Influence of types of restorative vegetation on the wetting properties of aggregates in a severely degraded clayey Ultisol in subtropical China. Geoderma 115:313-324. https://doi.org/10.1016/S0016-7061(03)00085-5

Rütting T, Boeckx P, Müller C, Klemedtsson L (2011) Assessment of the importance of dissimilatory nitrate reduction to ammonium for the terrestrial nitrogen cycle. BG 8:1779-1791. https://doi.org/10.5194/ bg-8-1779-2011

Ryżak M, Bieganowski A (2011) Methodological aspects of determining soil particle-size distribution using the laser diffraction method. J Plant Nutr Soil Sci 174:624-633. https://doi.org/10.1002/jpln. 201000255

Sagar NA, Pareek S, Sharma S, Yahia EM, Lobo MG (2018) Fruit and vegetable waste: bioactive compounds, their extraction, and possible utilization. Compr Rev Food Sci Food 17:512-531. https://doi.org/ 10.1111/1541-4337.12330

Shokri N, Or D (2011) What determines drying rates at the onset of diffusion controlled stage-2 evaporation from porous media? Water Resour Res 47:W09513. https://doi.org/10.1029/ 2010WR010284

Silver WL, Herman DJ, Firestone MK (2001) Dissimilatory nitrate reduction to ammonium in upland tropical forest soils. Ecology 82: 
2410-2416. https://doi.org/10.1890/0012-9658(2001)082[2410: DNRTAI]2.0.CO;2

Urbanek E, Hallett P, Feeney D, Horn R (2007) Water repellency and distribution of hydrophilic and hydrophobic compounds in soil aggregates from different tillage systems. Geoderma 140:147-155. https://doi.org/10.1016/j.geoderma.2007.04.001

Vitousek PM, Hättenschwiler S, Olander L, Allison S (2002) Nitrogen and nature. Ambio 31:97-101. https://doi.org/10.1579/0044-744731.2.97

Vogelmann ES, Reichert JM, Prevedello J, Awe GO, Cerdà A (2017) Soil moisture influences sorptivity and water repellency of topsoil aggregates in native grasslands. Geoderma 305:374-381. https://doi.org/ 10.1016/j.geoderma.2017.06.024

Wang J, Fu X, Zhang Z, Li M, Cao H, Zhou X, Ni H (2019) Responses of soil respiration to nitrogen addition in the Sanjiang Plain wetland, northeastern China. PLoS One 14:e0211456. https://doi.org/10. 1371/journal.pone.0211456

Wang Z, Wu QJ, Wu L, Ritsema CJ, Dekker LW, Feyen J (2000) Effects of soil water repellency on infiltration rate and flow instability. J
Hydrol 231-232:265-276. https://doi.org/10.1016/S0022-1694(00) 00200-6

Włodarczyk T, Szarlip P, Koziel W, Nosalewicz M, Brzezińska M, Pazur M, Urbanek E (2014) Effect of long storage and soil type on the actual denitrification and denitrification capacity to $\mathrm{N}_{2} \mathrm{O}$ formation. Int Agrophys 28:371-381. https://doi.org/10.2478/intag-2014-0027

Yilmaz E (2014) Assessment of the role of agricultural wastes in aggregate formation and their stability. J Environ Manag 144:93-100. ISSN 0301-4797. https://doi.org/10.1016/j.jenvman.2014.05.023

Zheng Z, Shetty K (2000) Enhancement of pea (Pisum sativum) seedling vigour and associated phenolic content by extracts of apple pomace fermented with Trichoderma spp. Process Biochem 36:79-84. https://doi.org/10.1016/S0032-9592(00)00183-7

Publisher's note Springer Nature remains neutral with regard to jurisdictional claims in published maps and institutional affiliations. 